\title{
Dilative Arteriopathy and Leucencephalopathy as Manifestations of a Neurometabolic Disease
}

\author{
Josef Finsterer $^{1, *}$ and Adam Bastovansky ${ }^{2}$ \\ ${ }^{1}$ Krankenanstalt Rudolfstiftung \\ ${ }^{2}$ Radiological Department, Krankenanstalt Rudolfstiftung, Vienna, Austria
}

\begin{abstract}
Background: Dilative arteriopathy plus leucencephalopathy as a manifestation of a mitochondrial disorder (MID) is rare.

Case report: In a 70 yo Caucasian female, height $160 \mathrm{~cm}$, weight $62 \mathrm{~kg}$, with mild right-sided hemiparesis due to subacute ischemic stroke in the posterior leg of the left internal capsule, a megadolichobasilar artery and marked leucencephalopathy and gliosis of the pons were detected. In addition, microbleeds in a peripheral distribution at the cortical/subcortical border were noted. After the exclusion of various differentials, which could have explained her abnormalities, a MID was suspected.

Conclusions: Dilative arteriopathy of the intra-cerebral arteries, in association with recurrent stroke and supra- and infratentorial leucencephalopathy, but the absence of neurofibromatosis or increased low-density lipoprotein values, is most likely attributable to a non-syndromic MID.
\end{abstract}

Keywords: Mitochondrial disorder, genetics, dilative arteriopathy, megadolichobasilar artery, arteriopathy, stroke.

Dilative arteriopathy is a vascular anomaly of the large extra- and intra-cerebral arteries consisting of the widening and elongation of the basilar and carotid arteries and the proximal anterior, medial and posterior cerebral arteries [6]. Dilative arteriopathy may manifest as ectasia or aneurysms [6]. It may be responsible for a number of cerebral manifestations such as vertigo, deafness, trigeminal neuralgia, facial spasms, facial palsy, hydrocephalus or stroke (Table 1) [9]. Occasionally, dilative arteriopathy is associated with leucencephalopathy. Dilative arteriopathy plus leucencephalopathy as a manifestation of a mitochondrial disorder (MID), as in the following case, is rare.

The patient is a 70-year-old Caucasian female, height 160 $\mathrm{cm}$, weight $62 \mathrm{~kg}$, who was admitted for mild right-sided hemiparesis one day after onset. Cerebral MRI revealed a subacute ischemic stroke in the posterior leg of the left internal capsule. In addition, marked leucencephalopathy and gliosis of the pons were evident. Furthermore, microbleeds in a peripheral distribution at the cortical/subcortical border were noted. She had a history of a prior left-sided stroke three years earlier in the parietal, subcortical white matter and of hypercholesterolemia. Other cardiovascular risk factors were negative. Blood chemical investigations were completely normal. There were no indications for endocrine,

*Address correspondence to this author at the Postfach 20, 1180 Vienna, Austria, Europe; Tel. +43-1-71165-92085; Fax. +43-1-4781711;

E-mail: fifigs1@yahoo.de cardiac or skeletal muscle abnormalities. The family history was negative for neurometabolic disease.

The patient is interesting as presenting with supra- and infra-tentorial leucencephalopathy in addition to dilative arteriopathy. Stroke as a manifestation of dilative arteriopathy is in line with previously reported cases of dilative arteriopathy and stroke (Table 1). Although the cause of cerebral white matter lesions remains elusive, Several differential diagnoses have to be discussed.

Dilative arteriopathy is a large vessel disease affecting the large intra- or extra-cranial cerebral arteries [6]. It has been associated with a number of disorders, including arterial hypertension [26], Fabry's disease [19, 27], neurofibromatosis [22], Pompe's disease [17], kidney dysfunction [12], low-density lipoprotein elevation [11] and non-syndromic MID [6, 29] (Table 2). In the majority of cases, angiography reveals fusiform dilation of the basilar artery, elongation of the top of the basilar trunk and asymmetric tortuosity or dislocation of the irregular shaped wall of the basilar artery [15].

Clinical manifestations of dilative arteriopathy are numerous and include vertigo [9], deafness [9, 21], trigeminal neuralgia $[9,28]$, facial spasms, usually hemispasms $[9,4]$, facial palsy [9], multiple cranial nerve palsy [25], compression hydrocephalus $[1,18,25]$, central alveolar hypoventilation [10], short-lasting unilateral neuralgiform headache 
Table 1. Clinical manifestations of dilative arteriopathy.

\begin{tabular}{|l|c|}
\hline Vertigo & {$[9]$} \\
\hline Deafness & {$[9,21]$} \\
\hline Trigeminal neuralgia & {$[9,28]$} \\
\hline Facial hemispasm & {$[4,9]$} \\
\hline Facial palsy & {$[2][1,18,25]$} \\
\hline Multiple cranial nerve palsy & {$[10]$} \\
\hline Hydrocephalus & {$[23]$} \\
\hline Central alveolar hypoventilation & {$[16]$} \\
\hline SUNCT syndrome & {$[5]$} \\
\hline Locked-in-syndrome with yawning & {$[20]$} \\
\hline Subarachnoid or intracerebral hemorrhaghe & {$[3,24]$} \\
\hline Agenesis of the internal carotid arteries & \\
\hline Stroke & {$[25]$} \\
\hline
\end{tabular}

SUNCT: short-lasting unilateral neuralgiform headache attacks with conjunctival injection and tearing

Table 2. Differential diagnoses of a mega-dolicho basilar artery.

\begin{tabular}{|c|c|c|}
\hline Disorder & Leucencephalopathy & Reference \\
\hline \hline Neurofibromatosis & Yes & {$[22]$} \\
\hline Fabry's disease & No & {$[8,19,27]$} \\
\hline Pompe disease & No & {$[17]$} \\
\hline Arterial hypertension & No & {$[14,26]$} \\
\hline Kidney disease & No & {$[11]$} \\
\hline Low-density lipo-protein & Yes & {$[2,6,7,29]$} \\
\hline Mitochondrial disorder & Yes & \\
\hline
\end{tabular}

attacks with conjunctival injection and tearing (SUNCT)syndrome [23] and stroke [3, 24] (Table 1). Of these, stroke is the most frequent.

Why dilative arteriopathy and leucencephalopathy in the presented patient were attributed to a non-syndromic MID, manifesting as leucencephalopathy exclusively is based on several arguments. The simultaneous occurrence of leucencephalopathy and dilative arteriopathy generally occurs in neurofibromatosis, low-density lipoprotein-associated dilated arteriopathy, or MID (Table 2). Neurofibromatosis was excluded based on the clinical presentation and the neuroradiological findings and a low-density lipoprotein-associated dilated arteriopathy based on the repeatedly normal lowdensity lipoprotein levels. As such, the most likely cause of dilated arteriopathy with leucencephalopathy in the patient presented remains a non-syndromic MID [7]. Further arguments for the MID are the patient's short stature and hyperlipidemia. The marginally-sized kidneys are an argument for kidney disease as the cause of dilative arteriopathy, but renal disease with dilative arteriopathy is not usually associated with leucencephalopathy.

This case shows that dilative arteriopathy of the large intra-cerebral arteries in association with supra- and infratentorial leucencephalopathy and normal low-density lipoprotein values is probably attributable to non-syndromic mitochondrial leucencephalopathy. Recurrent stroke may be a manifestation of dilative arteriopathy. 


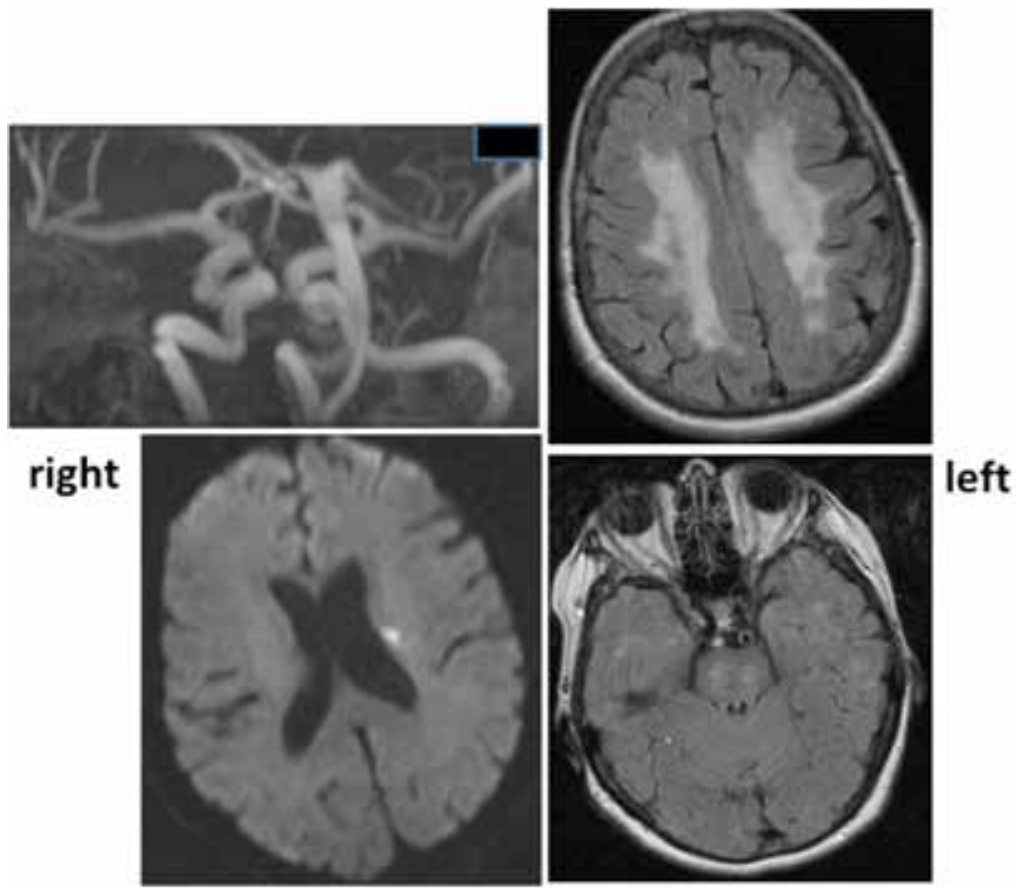

Fig. (1). Cerebral imaging of the described patient. Ektasia of the basilary artery (upper left). Periventricular ischemic stroke in the territory of the left median cerebral artery (lower left). Supratentorial leucencephalopathy (upper right). Leucencephalopathy of the pons (lower right).

\section{CONFLICT OF INTEREST}

The author confirms that this article content has no conflict of interest.

\section{ACKNOWLEDGEMENTS}

Declared none.

\section{REFERENCES}

Aiba T, Nakazawa T. Non-communicating hydrocephalus due to megadolichobasilar artery--case report. Neurol Med Chir (Tokyo) 1995; 35:104-6.

[2] Byrne E. Does mitochondrial respiratory chain dysfunction have a role in common neurodegenerative disorders? J Clin Neurosci 2002; 9:497-501.

[3] Cambron M, Van Hooff RJ, Nieboer K, De Keyser J, Brouns R. Successful repetitive intravenous thrombolysis in a patient with recurrent brainstem infarctions due to megadolichobasilar ectasia. JAMA Neurol 2013; 70:520-1.

[4] Campos E, Matías-Guíu J, Romero F, Fernández JM, Dávalos A. Megadolichobasilar: presentation as facial hemispasm. Med Clin (Barc) 1984; 82:332.

[5] D'Andrea F, Maiuri F, Gangemi M, Iaconetta G. Megadolichobasilar anomaly. Clinical and diagnostic considerations on 30 cases. Acta Neurol (Napoli) 1992; 14:611-9.

[6] Finsterer J. Dilative arteriopathy in metabolic myopathies, particularly Pompe's disease. Acta Neurol Belg 2012; 112:15-8.

[7] Finsterer J, Mahjoub SZ. Primary mitochondrial arteriopathy. Nutr Metab Cardiovasc Dis 2012; 22:393-9.

[8] Garzuly F, Maródi L, Erdös M, Grubits J, Varga Z, Gelpi E, Rohonyi B, Mázló M, Molnár A, Budka H. Megadolichobasilar anomaly with thrombosis in a family with Fabry's disease and a novel mutation in the alpha-galactosidase A gene. Brain 2005; 128:2078-83.

[9] Guiral H, Risco J, Ferrer F. Otoneurological manifestations of basilar dolicoectasia. A report of six cases. Acta Otorrinolaringol Esp 1997; 48:337-40.
[10] Heckmann JG, Ernst S. Central Alveolar Hypoventilation (Ondine's Curse) Caused by Megadolichobasilar Artery. J Stroke Cerebrovasc Dis 2013; doi:pii:S1052-3057(13)00031-1. 10.1016/j.jstrokecerebrovasdis.2013.02.003.

[11] Ichikawa H, Mukai M, Ohno H, Shimizu Y, Itaya K, Kawamura M. Dee white matter hyperintensities, decreased serum low-density lipoprotein, and dilative large arteriopathy. J Stroke Cerebrovasc Dis 2012; $21: 225-30$.

[12] Ichikawa H, Takahashi N, Mukai M, Katoh H, Akizawa T, Kawamura M. Intracranial dilative arteriopathy is associated with chronic kidney disease and small vessel diseases in the elderly. J Stroke Cerebrovasc Dis 2009; 18:435-42.

[13] Ishikawa T, Nagayama M, Iida M, Shinohara Y. Bulbovascular compression by megadolichobasilar artery manifested as neurogenic and refractory hypertension. Rinsho Shinkeigaku 2004; 44:359-64.

[14] Ikeda K, Iwasaki Y. Megadolichobasilar artery and neurogenic hypertension. Rinsho Shinkeigaku 2004; 44:707-10.

[15] Klinge $\mathrm{H}$, Braunsdorf WE. Clinical signs associated with megadolichobasilar artery anomaly. Neurosurg Rev 1991; 14:303-7.

[16] Krasnianski M, Gaul C, Neudecker S, Behrmann C, Schlüter A, Winterholler M. Yawning despite trismus in a patient with lockedin syndrome caused by a thrombosed megadolichobasilar artery. Clin Neurol Neurosurg 2003; 106:44-6.

[17] Laforêt P, Petiot P, Nicolino M, Orlikowski D, Caillaud C, Pellegrini N, Froissart R, Petitjean T, Maire I, Chabriat H, Hadrane L, Annane D, Eymard B. Dilative arteriopathy and basilar artery dolichoectasia complicating late-onset Pompe disease. Neurology 2008; 70:2063-6.

[18] Lemke AJ, Sander B, Benndorf G, Balzer J, Boerschel MF, Hosten N, Sprung C, Ricke J, Felix R, Lanksch WR. Megadolichobasilar artery as a rare cause of hydrocephalus internus: synopsis of modern imaging methods. Aktuelle Radiol 1995; 5:310-4.

[19] Mitsias P, Levine SR. Cerebrovascular complications of Fabry's disease. Ann Neurol 1996; 40:8-17.

[20] Okabe S, Oda N, Ishii M. Agenesis of left internal carotid artery associated with megadolichobasilar anomaly and olivopontocerebellar atrophy. Rinsho Shinkeigaku 1989; 29:1395-400.

[21] Otterstedde CR, Tischendorf M, Reisser C. Megadolichobasilar artery as the etiology of sensorineural deafness in differential sudden deafness diagnosis. HNO 1999; 47:494-6. 
[22] Roth C, Gaiser T, Nagelmeier I, Rüschoff J, Ferbert A. Type I neurofibromatosis and megadolichobasilar artery. Nervenarzt 2007; 78:1195-9.

[23] Santos-Garcia D, Prieto JM, Blanco-Gonzalez M, Iglesias-Gomez S, Rodriguez-Constenla I, Lema M. SUNCT syndrome secondary to megadolichobasilar anomaly. Rev Neurol 2005; 41:638-9.

[24] Shirakuni T, Tamaki N, Matsumoto S, Fujiwara M. Megadolichobasilar anomaly associated with brain stem infarction: a case report. J Comput Tomogr 1985; 9:79-81

[25] Uncini A, Lugaresi A, Porrini AM, Gallucci M. Recurrent cranial nerve palsies, midbrain infarction and hydrocephalus due to megadolichobasilar artery. Ital J Neurol Sci 1990; 11:489-92.
[26] Unkelbach MH, Radeloff A, Bink A, Gstöttner W, Ziemann U. Megadolichobasilar anomaly causing acute deafness with vertigo. HNO 2008; 56:62-4.

[27] Uyama E. Fabry disease in light of recent review. Brain Nerve 2008; 60:1235-44.

[28] Yoshida M, Asano M. Direct compression by megadolichobasilar anomaly as a cause of trigeminal neuralgia; a case diagnosed by MRI. Tohoku J Exp Med 1994; 172:327-32.

[29] Zhang ZQ, Niu ST, Liang XH, Jian F, Wang Y. Vascular involvement in the pathogenesis of mitochondrial encephalo-myopathies. Neurol Res 2010; 32:403-8.

(C) Finsterer and Bastovansky; Licensee Bentham Open.

This is an open access article licensed under the terms of the Creative Commons Attribution Non-Commercial License (http://creativecommons.org/licenses/ by-nc/3.0/) which permits unrestricted, non-commercial use, distribution and reproduction in any medium, provided the work is properly cited. 